\title{
Communication
}

\section{EFFECT OF DIETARY POLYCHLORINATED BIPHENYLS (PCB) FOR INCREASING URINARY ASCORBIC ACID AND PLASMA CHOLESTEROL LEVELS IN RATS}

\author{
Takeshi TANI, Norihisa KATO, and Akira YoshIDA ${ }^{1}$ \\ Department of Agricultural Chemistry, Nagoya University, \\ Chikusa-ku, Nagoya 464, Japan
}

(Received August 1, 1980)

\begin{abstract}
Keywords PCB, urinary ascorbic acid, drug-metabolizing enzyme, plasma cholesterol
\end{abstract}

We previously reported that dietary addition of polychlorinated biphenyls (PCB) caused an increase in the activity of liver microsomal drug-metabolizing enzymes, plasma cholesterol and urinary ascorbic acid in rats (1). These metabolic responses have been also reported with other xenobiotics, including 1,1,1-trichloro2,2-bis ( $p$-chlorophenyl)ethane (DDT), 2,6-di-tert-butyl-p-cresol (BHT), caffein, phenobarbital and pentobarbital (2-4). Subsequent investigations showed a strong dependence of the metabolic responses upon dietary protein $(5,6)$ and ascorbic acid(7). In addition, it was demonstrated that dietary PCB induced hepatic cholesterol and ascorbic acid synthesizing enzymes $(8,9)$. These investigations were done using relatively high levels of xenobiotics as compared with the levels of environmental contamination. The present experiment was, therefore, designed to determine the limit of the dietary level of PCB which can affect the detectable metabolic responses, aiming at the possible use of increased urinary excretion of ascorbic acid as an indicator of dietary contamination by PCB.

Male rats of the Wistar strain (95-105 g) were maintained on the test diet for 30-31 days. The basal diet was composed of casein $30 \%$, corn oil $5 \%$, vitamin mixture $0.5 \%(10)$ without ascorbic acid, salt mixture $5 \%(10)$, choline chloride $0.2 \%$, cholecalciferol 4,000 IU per $\mathrm{kg}$ diet, retinyl acetate $10,000 \mathrm{IU}$ per $\mathrm{kg}$ diet, tocopheryl acetate $100 \mathrm{mg}$ per $\mathrm{kg}$ diet, $\mathrm{Se}\left(\right.$ as $\mathrm{Na}_{2} \mathrm{SeO}_{3}$ ) $0.1 \mathrm{mg}$ per $\mathrm{kg}$ diet and $59.3 \%$ carbohydrate containing one part of sucrose and two parts of gelatinized corn starch. PCB (Aroclor 1248) was added to the diet at the level of 5, 10, 10, 30, or $100 \mathrm{ppm}$. After killing the rats, liver homogenate $(12.5 \% \mathrm{w} / \mathrm{v})$ was prepared with ice-cold $1.15 \% \mathrm{KCl}$ in $0.01 \mathrm{M}$ phosphate buffer, $\mathrm{pH} 7.4$ using a Potter-Elvehjem homogenizer. The crude homogenate was spun at $10,000 \times g$ for $10 \mathrm{~min}$ and the postmitochondrial supernatant was used for the assay of aminopyrine $\mathrm{N}$ demethylase activity. The assay system for the demethylase activity has been

\footnotetext{
1 谷 武司, 加藤範久, 吉田 昭
} 
described previously (5). Urine was collected in 5\% metaphosphoric acid solution, centrifuged at $5,000 \times g$ and used for determination of ascorbic acid. A portion of liver and spleen was homogenized with 5\% metaphosphoric acid solution and then centrifuged. Ascorbic acid in the metaphosphoric acid extracts of tissue and urine was determined by the 2,4-dinitrophenylhydrazine method(11). Liver lipids were extracted by the method of Folch et al.(12) and used for the determination of cholesterol and total lipids. Cholesterol in plasma and liver was measured by the method of Pearson et al. (13). Liver total lipids was gravimetrically determined.

In accordance with our previous reports $(1,5)$, dietary PCB caused an increase in the activity of aminopyrine demethylase, tissue and urinary ascorbic acid and plasma cholesterol (Table 1). The result also showed a strong correlation between the demethylase activity and plasma cholesterol level (correlation coefficient $r=0.96$ ), which confirmed the results of our previous studies(1). The supplementation with $5 \mathrm{ppm}$ of PCB significantly increased liver concentration of ascorbic acid $(p<0.05)$. However, $10 \mathrm{ppm}$ of PCB was needed for the significant increase in urinary ascorbic acid and aminopyrine demethylase activity. The detectable increase in plasma cholesterol and liver total lipids was found with $30 \mathrm{ppm}$ or more of PCB. Previously, we considered the possibility that measurement of urinary ascorbic acid might be possible method for the detection of food contaminants(1). We reported that dietary addition of PCB gradually increased urinary ascorbic acid for at least 24 days, the significant increase being observed in a quite early period, even 2 days after the addition of PCB(5). Although the detectable levels are higher than those found in environmental contamination, this method might still be an useful for screening since it is usable with a variety of xenobiotics and is quite simple to perform.

The increase in tissue and urinary ascorbic acid due to PCB led us the assumption that dietary PCB might increase ascorbic acid requirement in the animals. This was verified by the demonstration of the increment in ascorbic acid requirement of guinea pigs receiving $\mathrm{PCB}(7)$. The significant increase in tissue ascorbic acid caused by $5 \mathrm{ppm}$ of $\mathrm{PCB}$ is obviously of importance in relation to public nutrition problems. In our present life, the exposure to a variety of xenobiotics through food chains, drug administration, smoking, etc. might lead to some increase in the requirement of vitamin C.

Recently, Ishikawa et al.(14) and our group (15) have showed the increase in high density lipoprotein (HDL) cholesterol due to PCB and other xenobiotics. Elevated HDL-cholesterol levels is a hypothetically protective factor against the development of coronary heart disease (16). The present result showed a significant increase in plasma cholesterol at levels of $30 \mathrm{ppm}$ of PCB or higher. A longer period of experiment is necessary to determine the effect of PCB on cholesterol levels in plasma and blood vessel wall. 


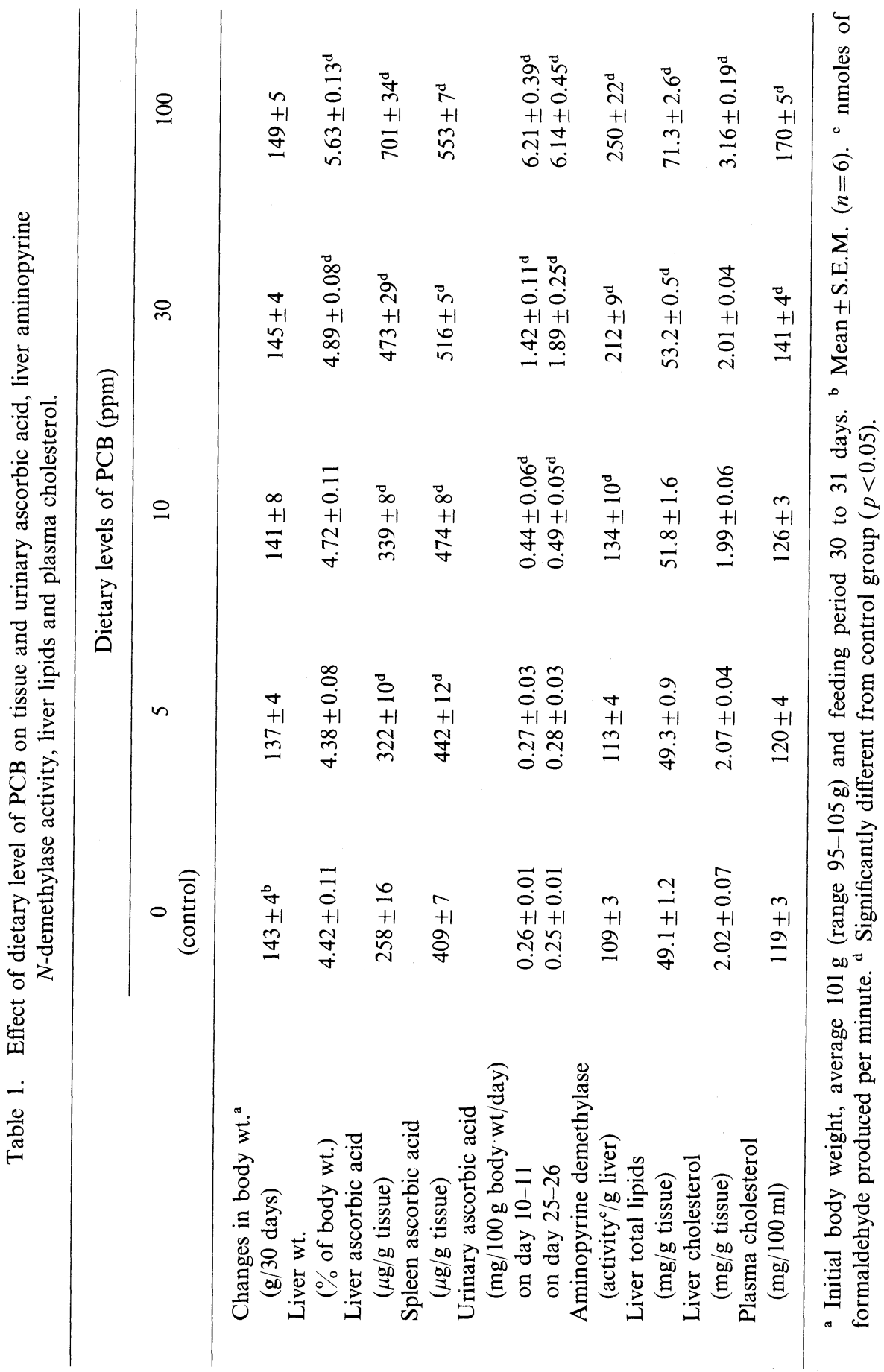

Vol. 26, No. 6, 1980 


\section{REFERENCES}

1) Kato, N. and Yoshida, A. (1979); Effects of some fat-soluble chemicals on plasma cholesterol and urinary ascorbic acid in rats. Agric. Biol. Chem., 43, 191-192.

2) Kato, N., Kato, M., Kimura, T., and Yoshida, A. (1978): Effect of dietary addition of PCB, DDT or BHT and dietary protein on vitamin A and cholesterol metabolism. Nutr. Rep. Int., 18, 437-445.

3) Magdolna, K., Robert, T., Magdolna, B., Erns, D., Magda, T. K., and Eva, W. J. (1968): Effect of caffeine and barbiturates on the metabolism of rats. Egeszsegutudomany, 13, 293-300.

4) Conney, A. H., and Burns, J. J. (1959): Stimulatory effect of foreign compounds on ascorbic acid biosynthesis and on drug-metabolizing enzymes. Nature, 184, 363-365.

5) Kato, N., Tani, T., and Yoshida, A. (1980): Effect of dietary level of protein on liver microsomal drug-metabolizing enzymes, urinary ascorbic acid and lipid metabolism in rats fed PCB-containing diets. J. Nutr., 110, 1686-1694.

6) Kato, N., Tani, T., and Yoshida, A. (1981): Effect of dietary quality of protein on liver microsomal mixed function oxidase system, plasma cholesterol and urinary ascorbic acid in the rats with or without receiving PCB. J. Nutr., 111, 17-27.

7) Kato, N., Okada, T., Takenaka, Y., and Yoshida, A. (1977): Ameliorative effect of dietary ascorbic acid on PCB toxicity in guinea pigs. Nutr. Rep. Int., 15, 125-130.

8) Kato, N., and Yoshida, A. (1980): Effect of dietary PCB on hepatic cholesterogenesis in rats. Nutr. Rep. Int., 21, 107-112.

9) Horio, F., and Yoshida, A., to be published.

10) Harper, A. E. (1959): Amino acid balance and imbalance. J. Nutr., 68, 405-418.

11) Ohara, T. (1973): Shokuhinbunseki Handbook, pp. 287-289, Kenpaku Co., Tokyo.

12) Folch, J., Lees, M., and Sloane Stanley, G. H. (1957): A simple method for the isolation and purification of total lipids from animal tissues. J. Biol. chem., 226, 497-507.

13) Pearson, S., Stern, S., and McGavack, T. H. (1953): A rapid, accurate method for the determination of total cholesterol in serum. Anal. Chem., 25, 813-814.

14) Ishikawa, T. T., McNeeley, S., Steiner, P. M., Glueck, C. J., Mellies, M., Gartside, P. S., and McMillin, C. (1978): Metabolism, 27, 89-96.

15) Kato, N., and Yoshida, A., in preparation.

16) Miller, G. J., and Miller, N. E. (1975): Plasma high density lipoprotein concentration and development of ischemic heart disease. Lancet, 1, 16-19. 